\title{
RADIOCARBON DATING AT THE UNIVERSITY OF WASHINGTON III
}

\author{
A. W. FAIRHALL, W. R. SCHELL and J. A. YOUNG \\ Department of Chemistry, University of Washington \\ Seattle, Washington
}

This date list consists of those measurements made since 1962. The counter is one described previously (Fairhall and Schell, 1963). The results are computed using NBS oxalic acid as the standard and 5568 for the half-life of $\mathrm{C}^{14}$. Standard deviations are computed for each measurement, including the statistical error in the sample count and uncertainties in background and standard. In general, each sample is counted at least twice. The quoted error on the date is the standard deviation. A $2 \sigma$ criterion is used to establish a lower limit to the age of very old samples with no detectable trace of $\mathrm{C}^{11}$. No correction for isotope fractionation has been made in any of the measurements.

During the time that samples UW-28 through UW-44 were measured, tritium from the 1961-1962 bomb tests began to appear in the hydrogen used to prepare the methane for counting (Fairhall et al., 1961) whereas our background gas was tritium-free. Before we became aware of this problem the results had been reported to the persons submitting the samples. Unfortunately some of these erroneous dates may have found their way into the literature. The extent of this problem was carefully investigated and the results reported here have been corrected for this tritium contamination. The problem has since been eliminated entirely by using hydrogen derived from petroleum, available from Air Products and Chemicals, Inc., Allentown, Pennsylvania.

\section{SAMPLE DESCRIPTIONS}

I. GEOLOGIC SAMPLES

$610 \pm 110$

\section{UW-28. Saanich Inlet, British Columbia}

A.D. 1340

Chip of wood $233 \mathrm{~cm}$ from top of core of varved mud from the bottom of Saanich Inlet, Vancouver Island, Canada $\left(48^{\circ} 35^{\prime} \mathrm{N}\right.$ Lat, $123^{\circ} 30^{\prime}$ W Long) . Sample had to be diluted three-fold to provide sufficient counting gas. Comment (M.G.G.) : established that the sediments show annual bands of diatom debris and provided an estimate of the rate of sediment deposition (Gross et al., 1963). Coll. and subm. by M. G. Gross, Univ. of Washington, Seattle.

\section{UW-31. Des Moines, Washington}

$36,800 \pm 1800$

34,850 в.c.

Wood from pre-Vashon deposit near Des Moines, Washington $\left(47^{\circ}\right.$ $27^{\prime} \mathrm{N}$ Lat, $122^{\circ} 17^{\prime} \mathrm{W}$ Long). From deposit of peat, silt, and clay encountered in water well beneath ca. $300 \mathrm{ft}$ of sand and gravel formed by advancing Vashon Glacier. Coll. 1962 and subm. by F. B. Roberts, Seattle Water Dept., Seattle. 
UW-32. Penn Cove, Whidbey Island, Washington 11,150 в.c.

Shells from glaciomarine drift along $\mathrm{N}$ shore of Penn Cove on Whidbey Island ( $48^{\circ} 14.6^{\prime} \mathrm{N}$ Lat, $122^{\circ} 42.5^{\prime} \mathrm{W}$ Long). Date establishes presence of late Pleistocene glaciomarine drift on Whidbey Island probably equivalent to similar drift in the Bellingham and Fraser delta areas. Coll. 1962 and subm. by D. J. Easterbrook, Western Washington State Coll., Bellingham.

\section{UW-35. Garcia, Washington \\ $13,570 \pm 130$ \\ 11,620 B.c.}

Wood from laminated silt and clay in section exposed on bank of $\mathrm{S}$ fork of Snoqualmie River ca. $1 / 3 \mathrm{mi}$ N of Garcia railroad station $\left(47^{\circ}\right.$ $26^{\prime} \mathrm{N}$ Lat, $121^{\circ} 38^{\prime} \mathrm{W}$ Long). Sediments were deposited in lake clammed by an end moraine of Puget glacier during Vashon Glaciation. Wood provides date for period of sedimentation. Coll. 1962 by R. C. Ellis; subm. by S. C. Porter, Univ. of Washington, Seattle.

\section{UW-48. Union, Washington}

Peat from ca. $5 \mathrm{ft}$ above road near mouth of Skokamish River ca. 21/2 mi SW of Union, Washington ( $47^{\circ} 19.7^{\prime} \mathrm{N}$ Lat, $123^{\circ} 07.1^{\prime} \mathrm{W}$ Long). Altitude of sampled peat layer ca. $25 \mathrm{ft}$. Overlain by a sequence up to $300 \mathrm{ft}$ thick of sand and gravel predominantly of Olympic Mountain provenance. Sequence contains glacial and nonglacial deposits overlain by Vashon Drift. Believed to be pre-Salmon Springs age. Coll. 1963 and subm. by J. B. Noble, Dept. of Conservation, Olympia.

UW-49. Hammersley Inlet, W ashington

$>\mathbf{4 5 , 0 0 0}$

Wood from beach bluff, ca. $8 \mathrm{ft}$ above high tide on $\mathrm{S}$ shore of Hammersley Inlet ca. $7 \mathrm{mi} \mathrm{E}$ of Shelton ( $47^{\circ} 12^{\prime} \mathrm{N}$ Lat, $122^{\circ} 57^{\prime} \mathrm{W}$ Long). Coll. 1963 and subm. by J. B. Noble. Comment (J.B.N.): samples ca. 10 $\mathrm{ft}$ above a till believed to be within Salmon Springs Drift. However, wood in non-glacial materials thought to be within the younger Kitsap Formation (Garling and Molenaar, 1965) would certainly date $>45,000$, and the significance of the date is not yet clear.

UW-50. Goldsborough Creek Valley, Washington $>40,000$

Wood from within a sequence of gravels of Olympic Mountain Provenance, mostly non-glacial, overlain by Vashon Drift, ca. $12 \mathrm{ft}$ above creek level. Located ca. $1 \mathrm{mi} \mathrm{W}$ of Shilton, $100 \mathrm{ft}$ downstream from toe of Rayonier-Simpson dam (47 $17^{\circ} 13^{\prime} \mathrm{N}$ Lat, $123^{\circ} 08^{\prime} \mathrm{W}$ Long). Coll. 1963 and subm. by J. B. Noble. Comment (J.B.N.) : sequence probably the same as the one that contained UW-48.

UW-53. Port Angeles, Washington

Wood from one of approx. 12 stumps, all of which are upright on a beach area on Straits of Juan de Fuca at a point ca. $2 \mathrm{mi} W$ of mouth 
of McDonald Creek and $9 \mathrm{mi} \mathrm{E}$ of Port Angeles $\left(48^{\circ} 07^{\prime} \mathrm{N}\right.$ Lat, $123^{\circ} 15^{\prime}$ W Long). Wave action is rapidly eroding a bank of interbedded outwash gravels, sands and silts overlying a 10-ft clay layer, the bank rising a total of ca. $100 \mathrm{ft}$ above high tide. Forest floor on which the trees would have been growing would be 0 to $5 \mathrm{ft}$ below high tide and has not been seen, but the large number of standing stumps 1 to $3 \mathrm{ft}$ in diam, most of them coniferous species, suggests strongly that they are rooted in place. Stumps are in an excellent state of preservation, as are shredded wood fragments and occasional small logs in or immediately below a 24-in. layer of peatlike material situated directly below clay and a few ft above stump horizon. Coll. 1963 and subm. by K. B. Bengtson, Richland, Washington.

UW-55. Seattle, Washington

$21,200 \pm 300$

19,250 в.c.

Wood in association with bones of a woolly mammoth found ca. 50

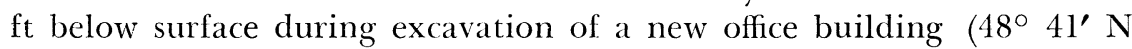
Lat, $122^{\circ} 18^{\prime} \mathrm{W}$ Long). Coll. 1963 by V. S. Mallory; subm. by W. A. Fairservis, Washington State Mus., Seattle.

\section{Platinum, Alaska series}

Basal peat from four bogs exposed in seacliffs 1 to $2 \mathrm{mi} \mathrm{N}$ of mouth of Salmon River near Platinum, Alaska (58 $52.8^{\prime} \mathrm{N}$ Lat, $161^{\circ} 46.8^{\prime} \mathrm{W}$ Long). Peat directly overlies drift of late Wisconsin age and dates provide minimum ages for deglaciation. Coll. 1963 and subm. by S. C. Porter.

UW-56. Platinum, Alaska No. 63627-2

$8910 \pm 110$

Peat from base of bog $1.9 \mathrm{mi} \mathrm{N}$ of Salmon River.

UW-57. Platinum, Alaska No. 63627-1

Peat from base of bog $1.6 \mathrm{mi} \mathrm{N}$ of Salmon River. Comment (S.C.P.) : sample age contrasts sharply with ages of basal peat from adjacent bogs. Reason is not known.

UW-70. Platinum, Alaska No. 63622-1

$12,840 \pm 170$

Peat from base of bog $1.2 \mathrm{mi} \mathrm{N}$ of Salmon River. 10,890 B.C.

UW-71. Platinum, Alaska No. 62622-2

$12,110 \pm 130$

Peat from bog $1.3 \mathrm{mi} \mathrm{N}$ of Salmon River.

10,160 в.C.

$\mathbf{5 0 5 0} \pm \mathbf{9 0}$

UW-62. Duwamish Valley, Washington

3100 B.c.

Wood fragments from a well located in postglacial alluvium ca. $2 \mathrm{mi}$ SW of Kent $\left(47^{\circ} 22^{\prime} \mathrm{N}\right.$ Lat, $122^{\circ} 15^{\prime} \mathrm{W}$ Long). Sample found in a layer 305 to $320 \mathrm{ft}$ below surface, overlain by $305 \mathrm{ft}$ of black silty sand. Beneath lay andesitic gravel and boulders in clay, 320 to $342 \mathrm{ft}$, and gray silty 
sand, 342 to $430 \mathrm{ft}$. Coll. 1963 and subm. by J. E. Luzier, U. S. Geol. Survey, Tacoma. Comment (J.E.L.) : date indicates that woody debris and underlying gravel and boulders in clay represent a lobe of Osceola Mudflow, ca. $65 \mathrm{mi}$ from its source on Mt. Rainier. Wood from outcrops of mulflow has been previously dated as $4800 \pm 450$ (L-223A), $4950 \pm 450$ (L-223B) and $4700 \pm 250$ (W-564; Crandell, 1963). Mudflow entered Puget Sound lowland while Duwamish Valley was still a long, deep marine embayment receiving sediment from the Green and Cedar rivers. A third river, the White, entered embayment after its diversion by the mudflow (Crandell, 1963) . Following this event, deposits of White River aggraded embayment above sealevel (Mullineaux, 1961).

\section{UW-63. Cherry Point, Washington}

Wood in till beneath late or post-Vashon glaciomarine deposits near base of seacliff $\mathbf{N}$ of Cherry Pt. on Georgia Strait at Aldergrove Rd. (48 52.5' N Lat, $122^{\circ} 46.2^{\prime}$ W Long). Coll. 1961 and subm. by D. J. Easterbrook, Bellingham, Washington. Comment: sample was previously measured (Dorn et al., 1962) as UW-17, with age reported as 24,200 \pm 2100 . Reason for discrepancy not known. See also comment under UW-67, below.

\section{UW-66. Ronald, Washington}

Flakes of charcoal from sandy silt of probably eolian origin that lies on top of thick gravel outwash body and underlies stoney till of maximum late-Wisconsin advance of Cle Elum valley glacier in cutback on $\mathrm{E}$ bank of Cle Elum River $1.7 \mathrm{mi} \mathrm{S}$ of Ronald, Washington $\left(47^{\circ} 12.6^{\prime} \mathrm{N}\right.$ Lat, $121^{\circ} 01.2^{\prime} \mathrm{W}$ Long). Coll. and subm. 1964 by S. C. Porter. Comment (S.C.P.) : sample apparently contaminated with flakes of Eocene coal which crops out upvalley.

\section{UW-67. Cormorant Passage}

Remeasurement of sample of peat originally dated (UW-19) at $33,000 \pm 1000$. This decrepancy along with those reported under UW-63 and UW-74 suggests that a systematic error may be present in all samples in our first date list (Dorn et al., 1962) which are older than ca. 20,000 yr. Although origin of this difficulty cannot be traced, it may have been due to inception of tritium problem mentioned in introduction. If this is the case only the very old samples would be significantly affected.

\section{UW-73. Snoqualmie Pass, Washington}

$7200 \pm 210$

$$
5250 \text { в.C. }
$$

Charcoal fragments from stream cut through bog at Snoqualmie Pass summit on U. S. Route $10\left(47^{\circ} 29.5^{\prime} \mathrm{N}\right.$ Lat, $121^{\circ} 24.9^{\prime} \mathrm{W}$ Long). Bog lies in kettle basin between 2 youngest recessional moraines of latest stage of last glaciation. Stratigraphic section exposes $1 \mathrm{ft}$ stony till at base, 2 to $3 \mathrm{ft}$ laminated lacustrine silt and clay, 1 in. organic matter from which sample was collected, 4 to 6 in. pale grayish-orange ash (Mazama ash), 
and $3 \mathrm{ft}$ organic silt and peat containing 2 thin ash layers of Mt. St. Helens origin. Coll. 1964 and subm. by S. C. Porter.

\section{UW -74. Johnson Point, Washington}

Peat from a 3 to 4 in. peat layer at top of Kitsap formation, comformably overlain by 3 to $4 \mathrm{in}$. of coarse sand with gravel up to $11 / 2 \mathrm{in}$. diam, grading upward to 8 to $10 \mathrm{ft}$ thick sequence of brown sand and gravel; underlain by fine sand and silt and several lower peat layers in a 10 to 15 ft thick section. Location ca. 5,000 ft $\mathrm{S}$ of and on E side of Johnson Point (47 $10.6^{\prime} \mathrm{N}$ Lat, $122^{\circ} 49.1^{\prime} \mathrm{W}$ Long). Coll. 1964 and subm. by D. Molenaar, Olympia. Comment: sample collected from same site, but possibly from different peat layer, as $\mathrm{UW}-7$, which was dated at $27,900 \pm 800$ (see comment under UW-67).

\section{ARCHAEOLOGIC SAMPLES}

A. Egypt

UW-30. Nubia, Egypt

$4660 \pm 100$

3710 B.C.

Charcoal from Afyeh, Nubia, on W bank of Nile $\left(22^{\circ} 30^{\prime} \mathrm{N}\right.$ Lat, $31^{\circ} 50^{\prime}$ E Long). From site AFH-1; Sq. A4; Locus B5-2.40 x A5-3.200.45 to 0.55 meters; Layer 3. Coll. 1962 by Shri B. Lal, New Delhi, India; subm. by W. A. Fairservis.

\section{B. Pakistan}

\section{Quetta Valley, W Pakistan series}

Charcoal samples from two sites in Quetta Valley, W Pakistan $\left(30^{\circ}\right.$ $10^{\prime} \mathrm{N}$ Lat, $67^{\circ} 00^{\prime} \mathrm{E}$ Long) . Coll. 1963 and subm. by Walter A. Fairservis.

\section{UW-59. Quetta Valley, No. Q8}

$4330 \pm 70$

Site Damb Sadlaat, Test Pit AT, Level 160, Damb Sadaat I. Comment (W.A.F.): sample is of particular interest since it represents Kechi Beg phase in Quetta Valley, which has typological ties to Pre-Harappan Kot Diji and Amri in Sind, suggesting that the beginning of the Harappan civilization there is probably ca. 2300 B.c.

\section{UW-60. Quetta Valley, No. MG}

$4030 \pm 160$ 2080 B.C.

Site Damb Sadaat, from Rubble Wall, Phase 1E, Damb Sadaat III. Comment (W.A.F.): from the level in Quetta Valley in which Harappan materials have been found.

UW-61. Quetta Valley, No. Q-24

$5260 \pm 80$ 3310 B.c.

Site Kile Gul Mohammad, Level 235T, upper levels of Kile Gul Mohammad I. Comment (W.A.F.) : sample represents last phases of the pre-, or aceramic, levels at the site. 


\title{
Chahsadda, W Pakistan series
}

Charcoal samples from excavations at Shaikhan Dheri (Chahsadda), a large city mound located near entrance to Khyber Pass $\left(34^{\circ} 00^{\prime} \mathrm{N}\right.$ Lat, $71^{\circ} 31^{\prime} \mathrm{E}$ Long). Site is important in that it represents early contact with the Mediterranean world and is associated with the reign of King Kanishka I. Coll. 1964 by A. H. Dani, Univ. of Peshawar; subm. by W. A. Fairservis.

\section{UW-77. Chahsadda, No. A4}

$2155 \pm 60$

From Site SHK, Location A4, Stratum 2, Pit 1.

205 B.c.

\section{UW-78. Chahsadda, No. B4}

$1940 \pm 70$

From Site SHK, Location B11, Stratum 3.

\author{
A.D. 10
}

\section{British Columbia and Washington}

\section{Beach Grove, British Columbia series}

Charcoal samples from a site near Beach Grove $\left(49^{\circ} 02^{\prime} \mathrm{N}\right.$ Lat, $123^{\circ}$ $04^{\prime}$ W Long), which, from cultural remains, is indicated as being of Marpole phase, one of the richest periods in cultural sequence of Fraser River delta area. Previous age determinations on samples from Marpole phase have ranged from 4th century B.C. to 2nd century A.D. Subm. by C. E. Borden, Univ. of British Columbia, Vancouver.

\section{UW-43. Beach Grove, No. UBC-1370}

$$
\begin{array}{r}
1540 \\
\text { A.D. } 410
\end{array}
$$

Charcoal from a stratum $18 \mathrm{ft} \mathrm{N}$ and $64 \mathrm{ft} \mathrm{W}$ of datum, $190 \mathrm{~cm}$ below surface, containing dark, charcoal-stained soil, with pea gravel and clam shell fragments. Coll. 1962 by P. D. Harrison. Comment (C.E.B.) : date indicates that Marpole phase lasted considerably longer than had been realized previously.

\section{UW-44. Beach Grove, No. UBC-2371}

$1600 \pm 120$

Charcoal from a stratum $18 \mathrm{ft} \mathrm{N}$ and 6 to $7 \mathrm{ft} \mathrm{W}$ of datum, $107 \mathrm{~cm}$ below surface, containing clay, clam, cockle and wood fragments. Coll. 1962 by J. H. Sendy. Comment (C.E.B.) : this date lends additional support to indications that Marpole lasted longer than had been known. Wooden wedges, cordage, and basketry remains found with this sample, are the oldest dated perishables of this kind known from the Northwest Coast.

\section{Columbia River, Washington series}

The following samples were collected between 1957 and 1962 in the archaeological salvage excavations in the reservoirs of Priest Rapids and Wanapum dams in Grant, Yakima and Kittitas Counties. Dates cover a 
span of time when the middle Columbia Valley was occupied by wandering hunters and gatherers whose essential patterns of living continued with relatively little change to the time of Euro-American settlement. One of the most significant innovations to occur during this period was the introduction of semi-subterranean dwellings for winter habitation between 1500 and $2000 \mathrm{yr}$ ago according to samples UW-40, UW-41, UW-41A, and UW-51, which bracket this event. The series also enables a more detailed ordering of artifact forms indicative of other aspects of culture change in the region. Subm. by R. E. Greengo, Univ. of Washington, Seattle.

\section{UW-37. Sourdough Creek}

$4200 \pm 125$

2250 в.C.

Fragmented animal bone from Indian midden site on alluvial fan at mouth of Sourdough Creek on $\mathrm{W}$ bank of Columbia River, $3.5 \mathrm{mi}$ upstream from Priest Rapids dam $\left(46^{\circ} 41^{\prime}\right.$ N Lat, $119^{\circ} 57^{\prime} \mathrm{W}$ Long). Samples in association with side-notched projectile points and bipoints, in what appeared to be a secondary deposit stratified under ca. $2 \mathrm{~m}$ of culturally sterile sands and silts. Coll. 1958 by R. E. Greengo. Comment (R.E.G.) : the large side-notched points appear to be an important horizon marker in the Northwest, and dating is toward the more recent temporal placing of this form elsewhere in the Columbia-Snake drainage.

\section{UW-39. French Rapids}

Charcoal from fireplace 40 to $52 \mathrm{~cm}$ below surface in Indian housepit on $\mathrm{W}$ bank of Columbia River, $2.3 \mathrm{mi}$ upstream from old Vantage bridge $\left(47^{\circ} 00^{\prime} \mathrm{N}\right.$ Lat, $120^{\circ} 00^{\prime} \mathrm{W}$ Long) . Coll. 1961 by R. S. Kidd. Comment (R.E.G.) : associated with small basal and corner-notched projectile points. Stratified below historic materials. Most recent date obtained thus far on late prehistoric Columbia River materials.

\section{UW-40. Crescent Bar}

$1250 \pm 70$

Charcoal from lowest level of occupation at $130 \mathrm{~cm}$ depth below surface at Indian house-pit site on S end of Crescent Bar, E bank of Columbia River, $14.5 \mathrm{mi}$ below Rock Island Dam $\left(47^{\circ} 11^{\prime} \mathrm{N}\right.$ Lat, $120^{\circ} 00^{\prime}$ W Long). Coll. 1961 by S. O. Solland. Comment (R.E.G.): associated with small basally notched projectile points and pentagonal points. Date is consistent with that of UW-38.

\section{UW-38. Vantage, E bank}

$$
1070 \pm 120
$$

$$
\text { A.D. } 880
$$

Charcoal from Indian house-pit site on $\mathrm{E}$ bank of Columbia River, ca. $13.5 \mathrm{mi}$ upstream from old Vantage bridge $\left(47^{\circ} 08^{\prime} \mathrm{N}\right.$ Lat, $120^{\circ} 00^{\prime} \mathrm{W}$ Long) . Coll. 1961 by R. E. Greengo. Comment (R.E.G.) : an acceptable date for Late Columbia Valley basally-notched point complex. 
UW-51. Vantage, W bank

$1170 \pm 200$

Charcoal from fireplace in lowest occupation stratum of House-pit 30 at $178 \mathrm{~cm}$ below surface. Located $14 \mathrm{mi}$ upstream from old Vantage bridge on W bank of Columbia River $\left(47^{\circ} 09^{\prime} \mathrm{N}\right.$ Lat, $120^{\circ} 00^{\prime} \mathrm{W}$ Long). Coll. 1960 by M. L. Susia. (Sample had to be diluted to provide enough gas for counting.) Comment (R.E.G.): dates late Columbia River basally and corner-notched points.

\section{Schaake Village subseries}

Samples from Indian house-pit site near mouth of Whiskey Dick Creek on $\mathrm{W}$ bank of Columbia River, $4.5 \mathrm{mi}$ upstream from old Vantage Bridge $\left(47^{\circ} 01^{\prime} \mathrm{N}\right.$ Lat, $122^{\circ} 00^{\prime} \mathrm{W}$ Long).

\section{UW-36. Schaake Village, Nos. 4116, 4273}

$3210 \pm 150$

Charcoal composite from a stratum $550 \mathrm{~cm}$ below datum and immediately above river gravels, associated with projectile points of small to medium size with rectangular to contracting stems generally regarded as markers of a middle prehistoric period on the Columbia. Coll. 1963 by B. G. Holmes.

\section{UW-41. Schaake Village, No. 2888}

Charred antler from below house-pit floors, but well above river gravel, $180 \mathrm{~cm}$ below datum (170 cm below surface). Coll. 1962 by B. G. Holmes. (Sample had to be diluted in order to provide enough gas for counting. Furthermore, antler is poor material for radiocarbon dating.) Comment (R.E.G.) : associated in a feature with a relatively large rectangular stemmed projectile point, a bone point, mountain sheep horn cores, and river mussel shells. Date not inconsistent with pre-house-pit context, but may be too recent.

\section{UW-41A. Schaake Village, No. 2071}

$2780 \pm 190$

830 B.C.

Charcoal from a stratum which represents a continuation of that represented in UW-41 at $230 \mathrm{~cm}$ below datum ( $175 \mathrm{~cm}$ below surface) Coll. 1962 by B. G. Holmes. Comment (R.E.G.): associated with a medium-sized contracting stem projectile point and mussel shell. Date is more consistent with this context than is UW-41, late in the middle period.

\section{UW-64. Schaake Village, No. 2860}

$$
1520 \pm 110
$$

Chacoal from house-pit fill $125 \mathrm{~cm}$ below datum. Coll. 1962 by B. G. Holmes. Comment (R.E.G.): this midden contains projectile points considered late in the Plateau, including corner-notched expandingstemmed forms, some with long barbs, unnotched triangular points small 
to medium in size, and a "Plateau Pentagonal" point. Date appears to be consistent with others with this complex of material.

Date lists:

\section{REFERENCES}

Lamont III Broecker, Kulp, and Tucek, 1956

Univ. of Washington I Dorn, Fairhall, Schell, and Takashima, 1962

USGS V Rubin and Alexander, 1960

Broecker, W. S., Kulp, J. L., and Tucek, C. S., 1956, Lamont natural radiocarbon measurements III: Science, v. 124, p. 154-165.

Crandell, D. R., 1963, Surficial geology and geomorphology of the Lake Tapps Quadrangle, Washington: U.S. Geol. Survey Prof. Paper 388-A, 84 p.

Dorn, T. F., Fairhall, A. W., Schell, W. R., and Takashima, Y., 1962, Radiocarbon dating at the University of Washington I: Radiocarbon, v. 4, p. 1-12.

Fairhall, A. W., Schell, W. R., and Takashima, Y., 1961, Apparatus for methane synthesis for radiocarbon dating: Rev. Sci. Instruments, v. 32, p. 323-325.

Fairhall, A. W., and Schell, W. R., 1963, Radiocarbon dating at the University of Washington II: Radiocarbon, v. 5, p. 80-81.

Garling, M. E., Molenaar, D., and others, 1965, Water resources and geology of the Kitsap Peninsula and certain adjacent islands: Water Supply Bull. no. 18, Washington Div. of Water Resources, Olympia, p. 29-31.

Gross, M. Grant, Jr., Glucluer, S. M., Creager, J. S., and Dawson, W. A., 1963, Varved marine sediments in a stagnant fjord: Science, v. 141, p. 918-919.

Krueger, H. W., 1965, The preservation and dating of collagen in ancient bones: Proceedings of the Internat. $\mathrm{C}^{14}$ and $\mathrm{H}^{3}$ Dating Conf., Pullman, Washington (in press).

Mullineaux, D. R., 1961, Geology of the Renton, Auburn, and Black Diamond Quadrangles, Washington: U.S. Geol. Survey Open-file Report, 202 p.

Rubin, Meyer, and Alexander, Corrinne, 1958, U.S. Geological Survev radiocarbon dates V: Am. Jour. Sci. Radioc. Supp., v. 2, p. 129-185. 